\title{
Are humanized lgE reporter systems potential game changers in serological diagnosis of human parasitic infection?
}

\author{
Prema S. Prakash $^{1}$ - Michael H. W. Weber ${ }^{1}$ Jaap J. van Hellemond ${ }^{2} \cdot$ Franco H. Falcone $^{1}$
}

Received: 26 July 2021 / Accepted: 16 October 2021 / Published online: 12 November 2021

(c) The Author(s) 2021

\begin{abstract}
Immunoglobulin $\mathrm{E}(\mathrm{IgE})$ is thought to have evolved to protect mammalian hosts against parasitic infections or toxins and plays a central role in the pathogenesis, diagnosis, and therapy of IgE-mediated allergy. Despite the prominence of IgE responses in most parasitic infections, and in stark contrast to its use in the diagnosis of allergy, this isotype is almost completely unexploited for parasite diagnosis. Here, we discuss the perceived or real limitations of IgE-based diagnosis in parasitology and suggest that the recent creation of a new generation of very sensitive cellular IgE-based reporters may represent a powerful new diagnostic platform, but needs to be based on a very careful choice of diagnostic allergens.
\end{abstract}

Keywords IgE $\cdot$ Diagnosis $\cdot$ RBL reporter system $\cdot$ Luciferase $\cdot$ Fluorescence

\begin{tabular}{|c|c|}
\hline \multicolumn{2}{|c|}{ Abbreviations } \\
\hline $\mathrm{CCD}$ & cross-reactive carbohydrate determinant \\
\hline DELFIA & $\begin{array}{l}\text { dissociation-enhanced lanthanide fluorescent } \\
\text { immunoassays }\end{array}$ \\
\hline ITAM & intracellular tyrosine activating motif \\
\hline ITIM & intracellular tyrosine inhibitory motif \\
\hline mRFP & monomeric red fluorescent protein \\
\hline NFAT & nuclear factor of activated T-cells \\
\hline NPY & neuropeptide Y \\
\hline RBL & rat basophilic leukemia cell line \\
\hline
\end{tabular}

\section{The relationship between parasites and IgE is old}

$\operatorname{IgE}$ is an immunoglobulin isotype only found in mammals (Hellman et al. 2017), where it is thought to have arisen from an early IgY gene duplication event (Warr et al. 1995). IgE is

Section Editor: Christoph G. Grevelding

Franco H. Falcone

franco.falcone@vetmed.uni-giessen.de

1 Biomedical Research Centre Seltersberg (BFS), Institute for Parasitology, Justus Liebig University Giessen, Giessen, Germany

2 Department of Medical Microbiology and Infectious Diseases, Erasmus MC University Medical Center, Rotterdam, The Netherlands commonly believed to be associated with protection against a range of common parasites ('worm hypothesis'), such as intestinal worms or blood flukes (Pritchard et al. 2020). An alternative or complementary hypothesis sees the function of IgE as protection against toxins ('toxin hypothesis') (Palm et al. 2012). As recently described, the environment at the time the earliest mammalian ancestors evolved some 200 Mio years ago (Hellman et al. 2017) was rich in toxins, parasites, and other allergenic sources (e.g., environmental or food) (Pritchard et al. 2020). This makes it likely that the presence of IgE conferred an evolutionary advantage to the early mammalian ancestors, leading to the preservation of the IgE immune response across all mammals (Pritchard et al. 2020). Therefore, an elevation of parasite-specific and total IgE is a frequent symptom of parasitic infection (Jarrett and Miller 1982), together with peripheral blood eosinophilia (Huang and Appleton 2016) and intestinal mastocytosis (Befus and Bienenstock 1979). The IgE elevation occurs in endoparasitic as well as ectoparasitic infections (or infestations), such as scabies (Arlian et al. 2004). Parasitespecific IgE elevation, however, is not only found in most (if not all) metazoan infections but also in several protozoan infections such as malaria (Perlmann et al. 1994), toxoplasmosis (Sin Yew Wong et al. 1993; Matowicka-Karna and Kemona 2014), leishmaniasis (Atta et al. 1998), or invasive entamoebiasis (Aceti et al. 1989).

In the context of this article, the term 'allergen' designates molecules (usually proteins) which are the target of a specific $\operatorname{IgE}$ response, i.e., which possess one or more 
epitopes recognized by IgE. 'Allergenicity' here is understood as the ability of multivalent allergens to induce activation of cells bearing the high-affinity IgE receptor FceRI (mainly mast cells and basophils, but also other leukocyte populations). The intrinsic ability of an allergen to induce a Th2-biased immune response in a naïve host, leading to the synthesis of specific IgE, will not be addressed here. The important property of allergenicity here is the ability of an allergen to engage more than one FceRI-bound IgE molecule, thereby clustering the receptor and inducing signal transduction, leading to cellular activation and mediator release. In this sense, only molecules that have more than one accessible epitope, within a certain distance of each other, are considered allergenic.

In a primary immune response, IgE is thought to result from either direct $\operatorname{IgM} \rightarrow \operatorname{IgE}$ or indirect, sequential $\mathrm{IgM} \rightarrow \mathrm{IgG} \rightarrow \operatorname{IgE}$ isotype switching (Xiong et al. 2012). Thus, IgE antibodies take longer to appear in blood than the other isotypes in primary infection. In human experimental infection with the hookworm Necator americanus, we were able to detect sensitization of peripheral blood basophils as soon as 5-6 weeks after primary infection by performing basophil activation tests (Falcone et al. 2009). This time point is a bit earlier than the appearance of parasite eggs in the feces of infected individuals known from the work of Geiger and colleagues, where eggs were first detected 68-72 days after infection (Geiger et al. 2008), but closer to the 47 days p.i. described by Ogilvie et al. (1978). Interestingly, and perhaps important in the context of this article, basophil sensitization occurred in the absence of measurable, specific IgE levels in serum (Falcone et al. 2009). A similar situation is seen in the aforementioned work by Ogilvie, where specific IgE levels could only be detected after a third and fourth infection (Ogilvie et al. 1978). The original self-infection report by Ball and Bartlett (1969), however, points to an even earlier possible time point for the appearance of $\operatorname{IgE}$ in primary helminth infection. In these experiments, four human volunteers, injected intradermally with serum obtained from the hookworm-infected donor (4 weeks p.i.) and challenged $72 \mathrm{~h}$ later with $N$. americanus extracts, all showed very strong Prausnitz-Küstner reactions (a now-disused test in which IgE-containing serum of an allergic donor was injected intradermally into a non-allergic individual). With the caveat of the low number of experimental replicates, this would suggest that anti-parasite $\operatorname{IgE}$ responses can become apparent as early as 4 weeks after the original infection, which also matches the earliest time point of basophil conversion found in our work with N. americanus (Falcone et al. 2009).

Hence, not only can parasite-specific IgE be formed as early as one month after (primary) infection, the absence of detectable IgE levels in serum in the presence of basophil sensitization points to another relatively simple, but currently underexploited fact: That a cellular readout for parasite-specific IgE is possibly superior to traditional methods (such as ELISA) in terms of sensitivity. As will be explained below, IgE crosslinking by matching allergens induces a powerful and fast multi-tiered cellular signal transduction cascade, in which a relatively modest engagement of a small percentage of IgE receptors on the surface results in a full cellular response within minutes after activation (Falcone et al. 2000) (Fig. 1). In the case of the IgE reporter systems, sensitivity is further enhanced, e.g., by the use of sensitive enzymatic reactions (e.g., luciferase, which adds another level of signal amplification).

When measuring IgE using ELISAs, competition of IgE with IgG, contained in much higher amounts in serum for the same epitopes, affects sensitivity, unless special measures for removal of $\operatorname{IgG}$ are taken (Kadooka et al. 2000). As will be discussed below, when using IgE reporter cell lines for IgE detection, such IgG removal is an inherent step of the protocol, as cells sensitized with IgE-containing serum overnight are washed before the activating antigen/allergen is added (Wan et al. 2014b). IgE is the isotype with the lowest concentration in serum. The reference range for total $\operatorname{IgE}$ concentrations in serum (e.g., 2-214 IU/mL (Martins et al. 2014)) depends on the population considered and the age of the individuals, but is, in any case, up to four or five orders of magnitude lower than total IgG levels. However, parasitespecific and total IgE levels can be considerably increased in parasitic infections, e.g., $1360 \pm 721 \mathrm{U} / \mathrm{mL}$ in urinary schistosomiasis or $2355 \mathrm{ng} / \mathrm{mL}(\sim 973 \mathrm{IU} / \mathrm{mL})$ in filarial tropical eosinophilia (Neva et al. 1975).

\section{Use of specific lgE for detection of parasite infection}

Despite the ubiquity of $\operatorname{IgE}$ responses in parasitic infection, not many authors have attempted to develop diagnostic technologies based on parasite-specific IgE detection. Notably, work from the laboratory of Shelley F. Walton has looked into IgE recognition of Sarcoptes scabiei antigens (Arlian et al. 2004; Walton et al. 2010), identifying a cysteine protease (Sar s 1), a serine protease ( $\operatorname{Sar}$ s 3 ), and glutathioneS-transferase (Sar s 8) as allergens (Dougall et al. 2005). The authors suggested the use of apolipophorin Sar s 14.3 as a diagnostic allergen using dissociation-enhanced lanthanide fluorescent immunoassays (DELFIA), resulting in 100\% sensitivity and $93.75 \%$ specificity. More importantly, the Der $p$ 14 homolog apolipophorin from dust mites did not appear to be cross-reactive, which would have severely limited the usefulness of the diagnostic method. However, the most recent guidelines for the diagnosis of human scabies published in 2020 do not recommend or include any serological methods for diagnosis (Engelman et al. 2020). Apart from 


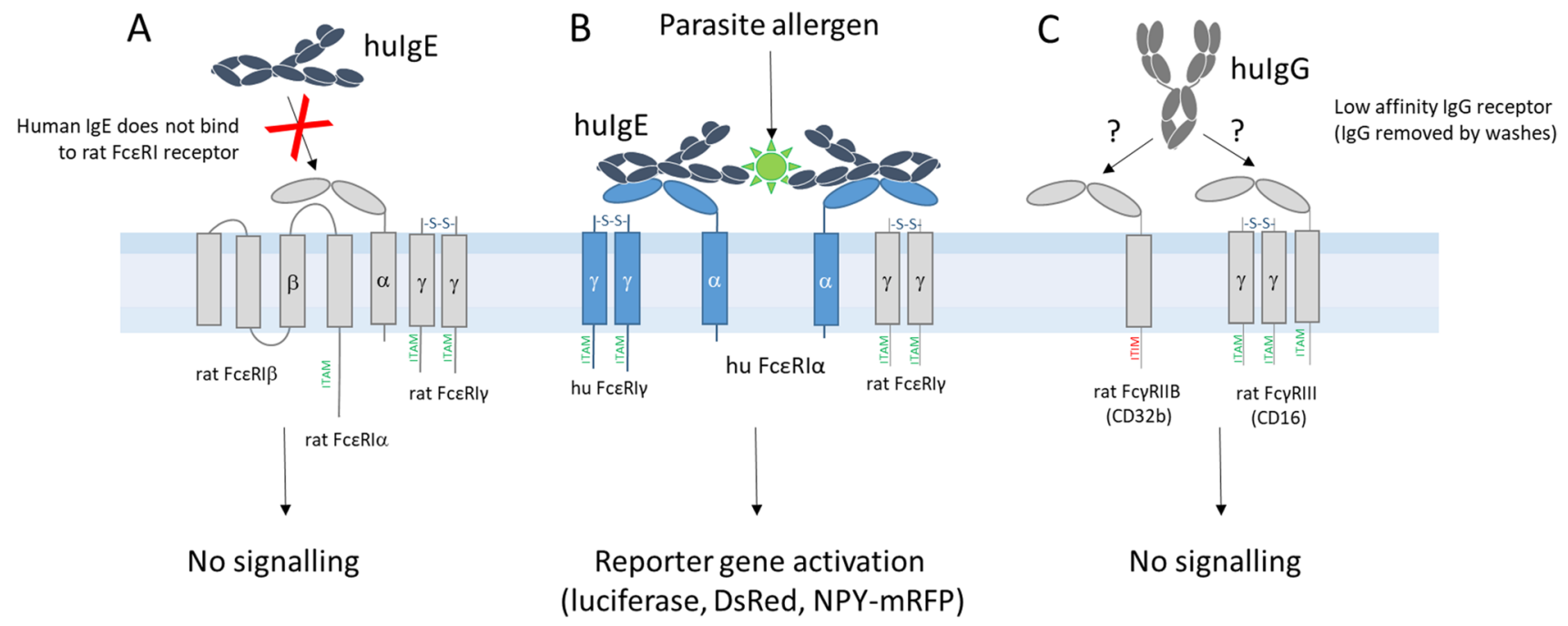

Fig. 1 How IgE reporter systems work. Existing IgE reporter systems are based on rat basophilic leukemia (RBL) cells, which are well studied and easy to grow (Falcone et al. 2018). However, because the rat high-affinity $\operatorname{IgE}$ receptor does not bind human $\operatorname{IgE}$ (A) (Miller et al. 1989), they need to be stably transfected with at least the alpha chain of FceRI, but best if co-transfected with the human gamma chain, as this results in higher surface expression (Ali et al. 2019) (B). RBL cells can also be tailored to bind equine (Sabban et al. 2013) or canine (Ye et al. 2014) IgE, and probably many other mammalian species. Cells are incubated overnight with IgE-containing sera to be tested, which increases the surface density of the receptor (Yamaguchi 1997). The next day, the diluted serum is washed away, removing any unbound $\operatorname{IgG}(\mathbf{C})$ or other potential sources of interference. RBL cells are known to constitutively express two low-affinity IgG receptors, Fc $\gamma$ RIIB (CD32b) and Fc $\gamma$ RIII (CD16) (Boček et al. 1995). While the former has an intracellular tyrosine inhibitory motif (ITIM) and is thus incapable of activating the reporter cell line, the latter has an intracellular tyrosine activating motif (ITAM) but can only be activated by immune complexes due to its low affinity for IgG (Boček et al. 1995). Therefore, although it is currently unknown to which extent human IgG can bind to rat Fc $\gamma$ RIIB and FcyRIII, most if not all of the $\operatorname{IgG}$ will be removed during the washes before the addition

the description of tropomyosin and paramyosin as immunoreactive allergens (Naz et al. 2017), no serological tests are available for human scabies infection (Arlian et al. 2015). Human scabies serological diagnosis, thus, remains problematic (Walton and Currie 2007). The high sensitivity and specificity of the aforementioned IgE-based scabies test can, however, be used to illustrate the potential of using IgE for the diagnosis of parasite infection.

The diagnostic potential of parasite-specific IgE has also been explored in toxoplasmosis, as reviewed by MatowickaKarna and Kemona (2014). Sensitivities reported in the reviewed studies ranged between $63 \%$ and $86.6 \%$, with $\operatorname{IgE}$ levels detected very early and persisting for half a year or longer. We speculate here that used in combination with $\operatorname{IgE}$ reporter systems, sensitivity could be strongly enhanced. A recent IgE-based ELISA for diagnosis of Strongyloides stercoralis infection in humans based on a recombinant allergen of the diagnostic allergen, avoiding any possible activation via $\mathrm{IgG}$. Some sera can be cytotoxic to RBL cells, requiring a 1:100 dilution or a short thermal inactivation $\left(5 \mathrm{~min}\right.$ at $\left.56^{\circ} \mathrm{C}\right)$, while other sera can be used, e.g., at 1:10 dilution without any pretreatment. The allergen is then added in a suitable concentration (usually in the range 0.1-1 $\mu \mathrm{g} / \mathrm{mL}$ ) and allowed to activate the sensitized reporter cells for various amounts of time, depending on the reporter gene used. Incubation times are shortest $(45 \mathrm{~min})$ for the NPY-mRFP RBL reporter (Barwary et al. 2020), which releases preformed fluorescent NPY-protein from the granules, 3-4 h for the RS-ATL8 (Nakamura et al. 2010), in which luciferase expression is induced, and 10-18 h (or longer if desired) for the NFAT-DsRed reporters (Wang et al. 2013), leading to the synthesis of red fluorescent protein in the cytosol in case of successful activation. In all cases, the high affinity of the receptor alpha chain for $\operatorname{IgE}\left(\mathrm{K}_{\mathrm{A}} \geq 10^{10} \mathrm{M}^{-1}\right)$ and slow dissociation rate ensures that $\mathrm{IgE}$ in the serum sample is efficiently bound by the cells, while the natural cellular signal transduction machinery provides powerful multi-tiered signal amplification, in combination with sensitive reporters (luciferase or fluorescent protein), providing further amplification. This combination makes such IgE reporters highly efficient in detection of small amounts of allergen-specific $\operatorname{IgE}$.

(rA133) demonstrated very high specificity (99.3\%) and sensitivity $(100 \%)$, although tested serum numbers were relatively small (Ahmad et al. 2021).

\section{Humanized IgE reporter systems are extremely sensitive}

While rat basophilic leukemia cells stably transfected with the human IgE receptor have been used for many years (Falcone et al. 2015), the last decade has seen the rather cumbersome and insensitive beta-hexosaminidase determination replaced by fluorescent or chemiluminescent reporter assays. These powerful IgE reporter cell lines can be used in a variety of formats, ranging from 384-well plates (Ali et al. 2017) to protein arrays (Kalli et al. 2020). The prototype, and to date still best performing IgE reporter system, was 
created by Ryosuke Nakamura and colleagues, who stably transfected a luciferase reporter into the humanized rat basophilic leukemia cell line RBL SX-38 (Nakamura et al. 2010), resulting in a cell line called RS-ATL8. RS-ATL8 cells are extremely sensitive, allowing detection of as little as $15 \mathrm{pg} /$ $\mathrm{mL}$ of IgE, 0.04 to $0.4 \mathrm{ng} / \mathrm{mL}$ allergen-specific IgE, or as little as $1 \mathrm{fg} / \mathrm{mL}$ of egg allergen using sera from egg-allergic patients. We later were able to demonstrate the suitability of RS-ATL8 cells in the context of Schistosoma mansoni infection (Wan et al. 2014a) and vaccine candidate screening (de Melo et al. 2019). Due to their unrivaled sensitivity, using $\operatorname{IgE}$ reporter systems for detection of specific IgE has many advantages but also some drawbacks, both summarized in Table 1.

A key confounding factor to consider is the high potential for cross-reactivity between parasitic and other (environmental or food) allergens. In the case of scabies, the occurrence of cross-reactive antibodies against house dust mites as confounding factor has been highlighted (Arlian et al. 2015). From this point of view, a diagnostic technology based on the detection of IgE should better avoid panallergens such as parvalbumins/polcalcins (Pritchard et al. 2020), tropomyosin or profilins (Hauser et al. 2010), and favor allergens that are unique to the parasite in question, or with restricted cross-reactivity, if at all possible. Bearing in mind the evolutionary hypothesis that the $\operatorname{IgE}$ response has evolved (at least in part) to protect the mammalian host against parasitic infection (Pritchard et al. 2020), which would favor recognition of 'archetypal' allergenic motifs, finding suitable allergens unique to a specific parasite may be a difficult proposition. However, it may still be possible to exploit subtle differences between the epitopes recognized by IgE.

Anisakis simplex needs to be discussed here briefly as a special case in parasitology and allergology, as this parasite plays a dual role as a zoonotic cause of infection (anisakiasis), and to a much larger extent also as a source of food allergens (Daschner et al. 2012). It is for its role in food allergy that A. simplex is the best-studied parasite in terms of its allergenicity, with at least 23 different allergens currently listed on the Allergome database (Mari et al. 2009). However, the high incidence of allergic sensitization due to ingestion of parasitized fish (Mazzucco et al. 2018), in addition to the known antigenic cross-reactivities with ascaridoid nematodes (Kennedy et al. 1988), also makes it highly unlikely that IgE-based detection can become a viable option for diagnosis of A. simplex infection.

Another potential issue, which is known to limit the clinical value of IgE-based diagnosis in allergy, is the existence of IgE directed against so-called cross-reactive carbohydrate determinants (CCDs) (Homann et al. 2017). CCDs are carbohydrate structures widely shared across allergens, which are the target of an IgE response. The most prominent example of CCD is galactose- $\alpha-(1,3)$-galactose ( $\alpha$-Gal), which is the determinant underlying red meat allergy (Steinke et al. 2015). In this syndrome, individuals develop an IgE response specific for $\alpha$-Gal, a carbohydrate linkage found in all mammals with the exception of higher apes and humans (Commins and Platts-Mills 2010), usually after sensitization due to repeated tick bites. This recently elucidated food allergy challenges current paradigms for several reasons (Iweala et al. 2020): (1) It is IgE-mediated, a reaction pattern usually classified as type I immediate hypersensitivity; however, symptoms in allergic patients occur several hours after red meat ingestion (Commins et al. 2016), making it the first example of a delayed-type, IgEmediated hypersensitivity; (2) the IgE is directed against a carbohydrate rather than protein determinant, but unlike most CCDs, it is still able to elicit clinical symptoms; and (3) from the parasitological point of view, as sensitization is linked to exposure to certain ticks and, as shown by us and others recently, to Ascaris lumbricoides (Wilson et al. 2021) (Murangi et al. 2021), it may represent the first example of food allergy induced by direct exposure (in contrast to ingestion) to parasites. IgE sensitization to $\alpha$-Gal induced disease may also go beyond food allergy, as suggested by a recent work implying a link with cardiovascular disease (Wilson and Platts-Mills 2019). The important fact to consider in the context of this article is that $\alpha-G a l$ sensitization can be detected using basophil activation assays, as recently shown by several authors (Commins et al. 2014; Hilger et al. 2016; Mehlich et al. 2019). However, we have been unable to detect activation of RS-ATL8 cells using sera of red meat allergic patients for reasons that still elude us.

Another important potential source of false-positive results in conventional serological methods caused by CCDs is the occurrence of a high level of cross-reactivity between parasite- and plant-derived glycans recognized by $\mathrm{IgG}$, as shown for Schistosoma mansoni in several studies by Michael J. Doenhoff and his co-workers (El-Faham et al. 2020; Igetei et al. 2017, 2018). However, the relevance of these findings for $\mathrm{IgE}$ responses has yet to be examined.

With the exception of $\alpha$-Gal-carrying allergens, the inability of most CCDs to crosslink receptor-bound IgE means that such allergens are unlikely to cause false-positive results in IgE reporter cell line assays, in contrast to assays measuring binding of specific IgE to allergens immobilized on a solid phase (Foetisch et al. 2003). Conversely, however, the observation that a large amount of IgE in Leishmaniasis appears to be directed against carbohydrate epitopes (Atta et al. 2004) implies that any leishmanial diagnostic allergens for use in IgE reporter systems, relying on effective IgE crosslinking by allergens, will have to be chosen carefully.

Taken together, parasite-specific IgE, despite its ubiquity in the immune response to parasites, is currently under-used as a diagnostic tool, in contrast to the use of allergen-specific 


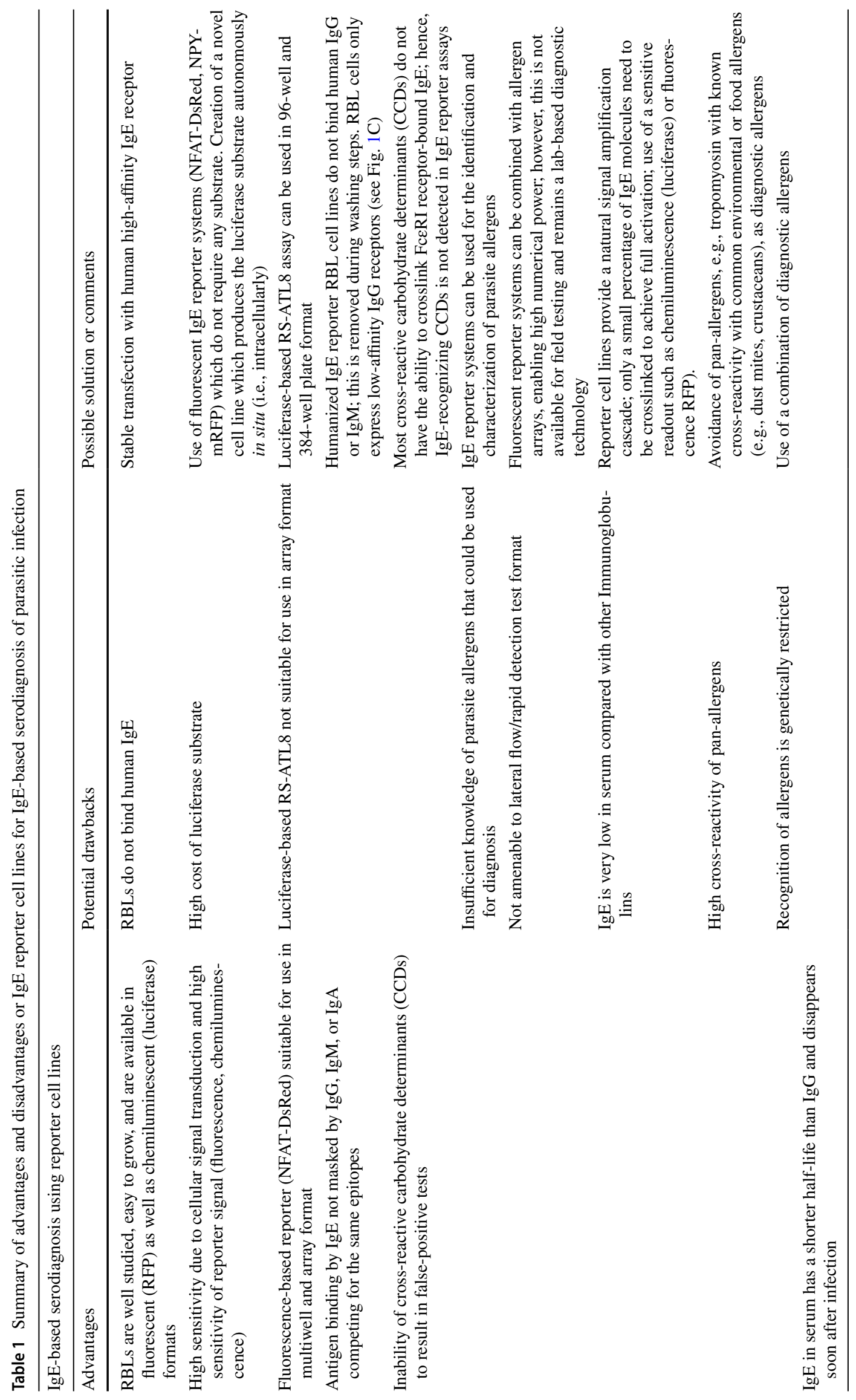


IgE in allergic diseases, where it plays a central role. The development of highly sensitive IgE reporter systems may play an important role in overcoming some of the real or perceived issues limiting the diagnostic use of $\operatorname{IgE}$ in parasite infections. However, implementing an IgE-based diagnostic system will require a careful choice of suitable allergens. Only then can the performance of such diagnostic systems be tested in a variety of parasitic disease settings.

Acknowledgements MHWW, PSP, and FHF are fully funded by the LOEWE Centre DRUID within the Hessian Excellence Initiative.

Funding Open Access funding enabled and organized by Projekt DEAL.

\section{Declarations}

Conflict of interest The authors declare no competing interests.

Open Access This article is licensed under a Creative Commons Attribution 4.0 International License, which permits use, sharing, adaptation, distribution and reproduction in any medium or format, as long as you give appropriate credit to the original author(s) and the source, provide a link to the Creative Commons licence, and indicate if changes were made. The images or other third party material in this article are included in the article's Creative Commons licence, unless indicated otherwise in a credit line to the material. If material is not included in the article's Creative Commons licence and your intended use is not permitted by statutory regulation or exceeds the permitted use, you will need to obtain permission directly from the copyright holder. To view a copy of this licence, visit http://creativecommons.org/licenses/by/4.0/.

\section{References}

Aceti A, Celestino D, Caferro M, Pennica A, Sebstiani A (1989) Total and specific $\mathrm{IgE}$ in sera from patients with invasive amoebiasis. Trop Geogr Med 41:151-153

Ahmad H, Arifin N, Nolan TJ, Lok JB, Anuar NS, Noordin R (2021) Strongyloides-specific IgE phage cDNA clones and development of a novel ELISA for strongyloidiasis. Diagnostics 11:985. https:// doi.org/10.3390/diagnostics11060985

Ali EA, Kalli M, Wan D, Nakamura R, Onion D, Alanine DGW, Alcocer MJC, Falcone FH (2019) Characterization of human FceRI $\alpha$ chain expression and gene copy number in humanized rat basophilic leukaemia (RBL) reporter cell lines. PLoS One 14(8):e0221034. https://doi.org/10.1371/journal.pone.0221034

Ali EA, Nakamura R, Falcone FH (2017) Use of humanized RS-ATL8 reporter system for detection of allergen-specific IgE sensitization in human food allergy. Methods Mol Biol. 1592:147-161. https:// doi.org/10.1007/978-1-4939-6925-8_12

Arlian LG, Feldmeier H, Morgan MS (2015) The potential for a blood test for scabies. PLoS Negl Trop Dis 9(10):e0004188. https://doi. org/10.1371/journal.pntd.0004188

Arlian LG, Morgan MS, Estes SA, Walton SF, Kemp DJ, Currie BJ (2004) Circulating IgE in patients with ordinary and crusted scabies. J Med Entomol 41:74-77. https://doi.org/10.1603/00222585-41.1.74

Atta AM, Colossi R, Sousa-Atta ML, Jeronimo SM, Nascimento MD, Bezerra GF, Orge G, Carvalho EM (2004) Antileishmanial $\mathrm{IgG}$ and $\mathrm{IgE}$ antibodies recognize predominantly carbohydrate epitopes of glycosylated antigens in visceral leishmaniasis. Mem Inst Oswaldo Cruz 99:525-530. https://doi.org/10.1590/S007402762004000500012

Atta AM, D'Oliveira Correa J, Atta ML, Almeida RP, Carvalho EM (1998) Anti-leishmanial IgE antibodies: a marker of active disease in visceral leishmaniasis. Am J Trop Med Hyg 59:426-430. https://doi.org/10.4269/ajtmh.1998.59.426

Ball PAJ, Bartlett A (1969) Serological reactions to infection with Necator americanus. Trans R Soc Trop Med Hyg 63:362-369. https://doi.org/10.1016/0035-9203(69)90011-X

Barwary NJS, Wan D, Falcone FH (2020) NPY-MRFP rat basophilic leukemia (RBL) reporter: a novel, fast reporter of basophil/mast cell degranulation. Methods Mol Biol 2163:163-170

Befus AD, Bienenstock J (1979) Immunologically mediated intestinal mastocytosis in Nippostrongylus brasiliensis-infected rats. Immunology 38:95-101

Boček P, Dráberová L, Dráber P, Pecht I (1995) Characterization of Fc $\gamma$ receptors on rat mucosal mast cells using a mutant FceRIdeficient rat basophilic leukemia line. Eur J Immunol 25:29482955. https://doi.org/10.1002/eji.1830251035

Commins SP, James HR, Stevens W, Pochan SL, Land MH, King C, Mozzicato S, Platts-Mills TA (2014) Delayed clinical and ex vivo response to mammalian meat in patients with IgE to galactosealpha-1,3-galactose. J Allergy Clin Immunol 134:108-15. https:// doi.org/10.1016/j.jaci.2014.01.024

Commins SP, Jerath MR, Cox K, Erickson LD, Platts-Mills T (2016) Delayed anaphylaxis to alpha-gal, an oligosaccharide in mammalian meat. Allergol Int 65:16-20

Commins SP, Platts-Mills TAE (2010) Allergenicity of carbohydrates and their role in anaphylactic events. Curr. Allergy Asthma Rep. 10:29-33

Daschner A, Cuéllar C, Rodero M (2012) The Anisakis allergy debate: does an evolutionary approach help? Trends Parasitol. 28:9-15. https://doi.org/10.1016/j.pt.2011.10.001

de Melo TT, Mendes MM, Alves CC, Carvalho GB, Fernandes VC, Pimenta DLF, de Moraes Mourão M, Gai F, Kalli M, Coelho A, de Azambuja Ribeiro RIM, Falcone FH, Pereira RADS, Fonseca CT (2019) The Schistosoma mansoni cyclophilin A epitope 107-121 induces a protective immune response against schistosomiasis. Mol Immunol 111:172-181. https://doi.org/10.1016/j.molimm. 2019.04.021

Dougall A, Holt DC, Fischer K, Currie BJ, Kemp DJ, Walton SF (2005) Identification and characterization of Sarcoptes scabiei and Dermatophagoides pteronyssinus glutathione S-transferases: implication as a potential major allergen in crusted scabies. Am J Trop Med Hyg 73:977-984. https://doi.org/10.4269/ajtmh.2005.73.977

El-Faham MH, Gai F, Igetei JE, Richter S, Falcone FH, Schramm G, Doenhoff MJ (2020) Antigenic cross-reactivity between Schistosoma mansoni and allergenic invertebrates putatively due to shared glycanic epitopes. Sci Rep 10:3350. https://doi.org/10. 1038/s41598-020-59892-6

Engelman D, Yoshizumi J, Hay RJ et al (2020) The 2020 International Alliance for the Control of Scabies Consensus Criteria for the diagnosis of scabies. Br J Dermatol 183:808-820. https://doi.org/ 10.1111/bjd.18943

Falcone FH, Alcocer MJC, Okamoto-Uchida Y, Nakamura R (2015) Use of humanized rat basophilic leukemia reporter cell lines as a diagnostic tool for detection of allergen-specific IgE in allergic patients: time for a reappraisal? Curr Allergy Asthma Rep 15:67. https://doi.org/10.1007/s11882-015-0568-3

Falcone FH, Haas H, Gibbs BF (2000) The human basophil: a new appreciation of its role in immune responses. Blood 96:4028-4038

Falcone FH, Telford G, Hooi D, Brown AP, Seabra R, Feary J, Venn A, Britton J, Pritchard DI (2009) Antigen-driven basophil activation is indicative of early Necator americanus infection in 
IgE-seronegative patients. J Allergy Clin Immunol 124:1343-50. e7. https://doi.org/10.1016/j.jaci.2009.07.039

Falcone FH, Wan D, Barwary N, Sagi-Eisenberg R (2018) RBL cells as models for in vitro studies of mast cells and basophils. Immunol. Rev. 282:47-57

Foetisch K, Westphal S, Lauer I, Retzek M, Altmann F, Kolarich D, Scheurer S, Vieths S (2003) Biological activity of IgE specific for cross-reactive carbohydrate determinants. J Allergy Clin Immunol 111:889-896. https://doi.org/10.1067/mai.2003.173

Geiger SM, Fujiwara RT, Santiago H, Corrêa-Oliveira R, Bethony JM (2008) Early stage-specific immune responses in primary experimental human hookworm infection. Microbes Infect 10:1524 1535. https://doi.org/10.1016/j.micinf.2008.09.003

Hauser M, Roulias A, Ferreira F, Egger M (2010) Panallergens and their impact on the allergic patient. Allergy Asthma Clin Immunol 6:1

Hellman LT, Akula S, Thorpe M, Fu Z (2017) Tracing the origins of $\mathrm{IgE}$, mast cells, and allergies by studies of wild animals. Front Immunol 8:1749

Hilger C, Fischer J, Swiontek K, Hentges F, Lehners C, Eberlein B, Morisset M, Biedermann T, Ollert M (2016) Two galactose- $\alpha$ 1,3-galactose carrying peptidases from pork kidney mediate anaphylactogenic responses in delayed meat allergy. Allergy Eur J Allergy Clin Immunol 71:711-719. https://doi.org/10.1111/all. 12835

Homann A, Schramm G, Jappe U (2017) Glycans and glycan-specific $\mathrm{IgE}$ in clinical and molecular allergology: sensitization, diagnostics, and clinical symptoms. J Allergy Clin Immunol 140:356368. https://doi.org/10.1016/j.jaci.2017.04.019

Huang L, Appleton JA (2016) Eosinophils in helminth infection: defenders and dupes. Trends Parasitol 32:798-807

Igetei JE, El-Faham M, Liddell S, Schramm G, Doenhoff MJ (2018) Antigenic cross-reactivity between Schistosoma mansoni and pollen allergens from the birch tree (Betula verrucosa) and Timothy grass (Phleum pratense): involvement of shared glycan epitopes and implications for the hygiene hypothesis. Int $\mathrm{J}$ Parasitol 48:345-357. https://doi.org/10.1016/j.ijpara.2017.12.005

Igetei JE, El Faham M, Liddell S, Doenhoff MJ (2017) Antigenic cross-reactivity between Schistosoma mansoni and peanut: a role for cross-reactive carbohydrate determinants (CCDs) and implications for the hygiene hypothesis. Immunology 150:506-517. https://doi.org/10.1111/imm.12711

Iweala OI, Choudhary SK, Addison CT et al (2020) Glycolipidmediated basophil activation in alpha-gal allergy. J Allergy Clin Immunol 146:450-452. https://doi.org/10.1016/j.jaci.2020.02.006

Jarrett EE, Miller HR (1982) Production and activities of IgE in helminth infection. Prog Allergy 31:178-233

Kadooka Y, Idota T, Gunji H, Shimatani M, Kawakami H, Dosako S, Samori T (2000) A method for measuring specific IgE in sera by direct ELISA without interference by IgG competition or IgG autoantibodies to IgE. Int Arch Allergy Immunol 122:264-269. https://doi.org/10.1159/000024408

Kalli M, Blok A, Jiang L, Starr N, Alcocer MJC, Falcone FH (2020) Development of a protein microarray-based diagnostic chip mimicking the skin prick test for allergy diagnosis. Sci Rep 10:18208. https://doi.org/10.1038/s41598-020-75226-y

Kennedy MW, Tierney J, Ye P, McMonagle FA, McIntosh A, McLaughlin D, Smith JW (1988) The secreted and somatic antigens of the third stage larva of Anisakis simplex, and antigenic relationship with Ascaris suum, Ascaris lumbricoides, and Toxocara canis. Mol Biochem Parasitol 31:35-46. https://doi.org/10. 1016/0166-6851(88)90143-0

Mari A, Rasi C, Palazzo P, Scala E (2009) Allergen databases: current status and perspectives. Curr Allergy Asthma Rep 9:376-83

Martins TB, Bandhauer ME, Bunker AM, Roberts WL, Hill HR (2014) New childhood and adult reference intervals for total IgE.
J Allergy Clin Immunol 133:589-591. https://doi.org/10.1016/j. jaci.2013.08.037

Matowicka-Karna J, Kemona H (2014) IgE antibodies in toxoplasmosis. Postepy Hig Med Dosw 68:597-602

Mazzucco W, Raia DD, Marotta C, Costa A, Ferrantelli V, Vitale F, Casuccio A (2018) Anisakis sensitization in different population groups and public health impact: a systematic review. PLoS One 13:e0203671. https://doi.org/10.1371/journal.pone.0203671

Mehlich J, Fischer J, Hilger C, Swiontek K, Morisset M, CodreanuMorel F, Schiener M, Blank S, Ollert M, Darsow U, Biedermann T, Eberlein B (2019) The basophil activation test differentiates between patients with alpha-gal syndrome and asymptomatic alpha-gal sensitization. J Allergy Clin Immunol 143:182-189. https://doi.org/10.1016/j.jaci.2018.06.049

Miller L, Blank U, Metzger H, Kinet JP (1989) Expression of highaffinity binding of human immunoglobulin $\mathrm{E}$ by transfected cells. Science 244:334-337

Murangi T, Prakash P, Moreira BP, Basera W, Botha M, Cunningham S, Facey-Thomas H, Halajian A, Joshi L, Ramjith J, Falcone FH, Horsnell W, Levin ME (2021) Ascaris lumbricoides and ticks associated with sensitisation to Galactose $\alpha 1,3$-galactose and elicitation of the alpha-gal syndrome. J Allerg Clin Immunol S0091-6749(21):01138-6. https://doi.org/10.1016/j.jaci.2021. 07.018

Nakamura R, Uchida Y, Higuchi M, Nakamura R, Tsuge I, Urisu A, Teshima R (2010) A convenient and sensitive allergy test: IgE crosslinking-induced luciferase expression in cultured mast cells. Allergy 65:1266-73. https://doi.org/10.1111/j.1398-9995. 2010.02363.x

Naz S, Desclozeaux M, Mounsey KE, Chaudhry FR, Walton SF (2017) Characterization of Sarcoptes scabiei tropomyosin and paramyosin: immunoreactive allergens in scabies. Am J Trop Med Hyg 97:851-860. https://doi.org/10.4269/ajtmh.16-0976

Neva FA, Kaplan AP, Pacheco G, Gray L, Danaraj TJ (1975) Tropical eosinophilia. A human model of parasitic immunopathology, with observations on serum IgE levels before and after treatment. J Allergy Clin Immunol 55:422-429. https://doi.org/10. 1016/0091-6749(75)90081-0

Ogilvie BM, Bartlett A, Godfrey RC, Turton JA, Worms MJ, Yeates RA (1978) Antibody responses in self-infections with Necator americanus. Trans R Soc Trop Med Hyg 72:66-71. https://doi. org/10.1016/0035-9203(78)90303-6

Palm NW, Rosenstein RK, Medzhitov R (2012) Allergic host defences. Nature 484:465-72. https://doi.org/10.1038/natur e11047

Perlmann H, Helmby H, Hagstedt M, Carlson J, Larsson PH, TroyeBlomberg M, Perlmann P (1994) IgE elevation and IgE antimalarial antibodies in Plasmodium falciparum malaria: association of high IgE levels with cerebral malaria. Clin Exp Immunol 97:284-292. https://doi.org/10.1111/j.1365-2249.1994.tb06082.x

Pritchard DI, Falcone FH, Mitchell PD (2020) The evolution of IgEmediated type I hypersensitivity and its immunological value. Allergy 76:1024-1040. https://doi.org/10.1111/all.14570

Sabban S, Ye H, Helm B (2013) Development of an in vitro model system for studying the interaction of Equus caballus IgE with its high-affinity receptor FceRI. Vet Immunol Immunopathol 153:10-6. https://doi.org/10.1016/j.vetimm.2013.01.008

Wong SY, Hajdu MP, Ramirez R, Thulliez P, McLeod R, Remington JS (1993) Role of specific immunoglobulin $\mathrm{E}$ in diagnosis of acute toxoplasma infection and toxoplasmosis. J Clin Microbiol 31:2952-2959. https://doi.org/10.1128/jcm.31.11.2952-2959. 1993

Steinke JW, Platts-Mills TAE, Commins SP (2015) The alpha-gal story: lessons learned from connecting the dots. J Allergy Clin Immunol 135:589-596 
Walton SF, Currie BJ (2007) Problems in diagnosing scabies, a global disease in human and animal populations. Clin Microbiol Rev 20:268-279

Walton SF, Pizzutto S, Slender A, Viberg L, Holt D, Hales BJ, Kemp DJ, Currie BJ, Rolland JM, O'Hehir R (2010) Increased allergic immune response to Sarcoptes scabiei antigens in crusted versus ordinary scabies. Clin Vaccine Immunol 17:1428-1438. https:// doi.org/10.1128/CVI.00195-10

Wan D, Ludolf F, Alanine DG, Stretton O, Ali Ali E, Al-Barwary N, Wang X, Doenhoff MJ, Mari A, Fitzsimmons CM, Dunne DW, Nakamura R, Oliveira GC, Alcocer MJ, Falcone FH (2014) Use of humanised rat basophilic leukaemia cell line RS-ATL8 for the assessment of allergenicity of Schistosoma mansoni proteins. PLoS Negl Trop Dis 8:e3124. https://doi.org/10.1371/journal. pntd.0003124

Wan D, Wang X, Nakamura R, Alcocer MJ, Falcone FH (2014) Use of humanized rat basophil leukemia (RBL) reporter systems for detection of allergen-specific IgE sensitization in human serum. Methods Mol Biol 1192:177-84. https://doi.org/10.1007/978-14939-1173-8_13

Wang X, Cato P, Lin HC, Li T, Wan D, Alcocer MJ, Falcone FH (2013) Optimisation and use of humanised RBL NF-AT-GFP and NFAT-DsRed reporter cell lines suitable for high-throughput scale detection of allergic sensitisation in array format and identification of the ECM-Integrin interaction as critical factor. Mol Biotechnol 56:136-146. https://doi.org/10.1007/s12033-013-9689-x

Warr GW, Magor KE, Higgins DA (1995) IgY: clues to the origins of modern antibodies. Immunol Today 16:392-398. https://doi.org/ $10.1016 / 0167-5699(95) 80008-5$
Wilson JM, Keshavarz B, James HR, Retterer MKC, Schuyler AJ, Knoedler A, Workman LJ, Ng'ang'a L, Chico ME, Rönmark E, Heymann PW, Perzanowski MS, Platts-Mills TAE, Cooper PJ (2021) $\alpha$-Gal specific-IgE prevalence and levels in Ecuador and Kenya: relation to diet, parasites, and IgG4. J Allergy Clin Immunol 147:1393-1401.e7. https://doi.org/10.1016/j.jaci.2020.12.650

Wilson JM, Platts-Mills TAE (2019) IgE to galactose- $\alpha-1,3$-galactose and the $\alpha$-Gal syndrome: insights from basophil activation testing. J. Allergy Clin Immunol 143:101-103

Xiong H, Dolpady J, Wabl M, Curotto de Lafaille MA, Lafaille JJ (2012) Sequential class switching is required for the generation of high affinity IgE antibodies. J Exp Med 209:353-364. https:// doi.org/10.1084/jem.20111941

Yamaguchi M (1997) IgE enhances mouse mast cell Fcepsilon RI expression in vitro and in vivo: evidence for a novel amplification mechanism in IgE-dependent reactions. J Exp Med 185:663-672. https://doi.org/10.1084/jem.185.4.663

Ye H, Housden JE, Hunter M, Sabban S, Helm BA (2014) Identification of amino acid residues involved in the interaction of canine IgE with canine and human FceRI $\alpha$. Mol Immunol 57:111-118. https://doi.org/10.1016/j.molimm.2013.08.013

Publisher's note Springer Nature remains neutral with regard to jurisdictional claims in published maps and institutional affiliations. 